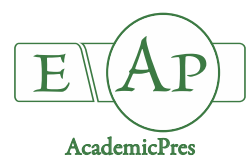

\title{
Natural Sources of Spraying to Preserve Apple Fruit Quality during Post-Harvest
}

\author{
Angelica A. ACEVEDO-BARRERA ${ }^{1}$, Juan M. SOTO PARRA ${ }^{1 *}$, \\ Rosa M. YAÑEZ-MUÑOZ ${ }^{1}$, Esteban SANCHEZ ${ }^{2}$, Ramona PEREZ-LEAL ${ }^{1}$ \\ ${ }^{1}$ Universidad Autónoma de Chihuahua, Facultad de Ciencias Agrotecnológicas, Campus Universitario I, Chibuahua, \\ México;aacevedo@uach.mx; jsoto@uach.mx(*correspondingauthor);myanez@uach.mx; rleal@uach.mx \\ ${ }^{2}$ Centro de Investigación en Alimentación y Desarrollo, A.C. Unidad Delicias, Chihuahua, México; esteban@ciad.mx
}

\begin{abstract}
One of the great challenges that apple producers face is to substantially improve the quality of fruit, including after harvest. A balanced and timely supply of calcium $(\mathrm{Ca})$ during growth and in the post-harvest stage is considered a technique that could improve shelf life and fruit quality; thus calcium plays a key role during post-harvest, with calcium carbonate and calcium sulphate being an alternative of foliar spraying. The study was carried out on 'Top Red' and 'Golden Delicious' apple cultivars, in a randomized complete block design with 13 treatments (referring to different commercial presentations of calcium) and 6 repetitions; 8 foliar sprays were applied weekly, from June 22 until harvest; 'Top Red' (151 days after full flowering, DDCF) and 'Golden Delicious' (145 DDCF) fruit were evaluated in regard with fruit traits (diameter, weight and colour) and maturity (pulp firmness, total soluble solids, titratable acidity and sugar acidity ratio). In 'Top Red' cv., calcium carbonate presented the best results, with intermediate to high quality apple fruit, while for cv. 'Golden Delicious' the best results were obtained with calcium sulphate, which increased fruits' diameter, weight, colour and titratable acidity. Even more, of the products evaluated, $\mathrm{CaCO}_{3}$ and $\mathrm{CaSO}_{4}$ had the lowest costs, and can be considered as good alternatives of foliar calcium supplement applied in order to preserve the quality of the apple during post-harvest.
\end{abstract}

Keywords: apple cultivars; calcium carbonate; calcium sulphate; storage

\section{Introduction}

Worldwide, more than 62 million tons of apples are annually produced (García-Muñoz et al., 2015) of which Mexico, in the year 2016 contributed with 716,931 tons on a sown area of $58,528 \mathrm{ha}^{-1}$, making it the fifteenth world producer of this fruit (SAGARPA, 2017). Due to the cultivated area, economic importance (Zermeño-González et al., 2009) and the social demand generated by its nutritional aspects, content of phenolic compounds and antioxidants (Flores et al., 2018), Malus domestica Borkh. is one of the most important temperate fruit trees in northeastern Mexico. The main producing states are Chihuahua, Coahuila and Durango (Zermeño-González et al., 2009) of which Chihuahua produces $74 \%$ of the apples nationwide (Romero et al., 2017). However, in Mexico, approximately $43 \%$ of apple cultivation is lost during postharvest period due to changes in quality characteristics, such as firmness, defects, external damage, microbial contamination and color changes (Cárdenas-Pérez et al., 2017), so it is a priority to substantially improve the quality, conservation capacity and shelf life of this fruit.
In Chihuahua, the majority of the apple crop is generally stored as a regulatory action of the markets. It must be added that during recent years, the United States imported apple had crowded the national market during periods closer to harvest intervals. In addition to market competition, the decline in refrigerated storage spaces becomes a serious problem. Among the ways in which this situation is addressed it can be noted the improvement of apple quality at harvest and post-harvest, improvement in its storage capacity and the ability to achieve a longer shelf life (Soto et al., 2016).

A balanced and timely supply of calcium (Ca) during growth and in the post-harvest stage is considered a technique that could improve shelf life and fruit quality (Flores et al., 2018), since its bivalent cations have been associated with physiological and pathological problems in fruit, with influence on the expression of physiological diseases and disorders in fruit trees (Castellano et al., 2006).

Calcium deficiency levels in the fruit has caused more and more frequent aspersions and immersions in different sources of $\mathrm{Ca}$, over different physiological stages of the crops, in order to decrease the physiological disorders induced by this problem (Lobos et al., 2011). 
In fruit trees, calcium plays a fundamental role because it performs multiple metabolic functions in both planting and post-harvest, affects the quality of the fruit and its storage resistance after harvest because it reduces the permeability of cell membranes, reduces water absorption, increases the hardness of the pulp, slows the senescence and controls different fruit and vegetable pathogens (Castellano et al., 2006; Pérez-Pérez et al., 2008; Soto et al., 2015; Mitre et al., 2018). When the Ca content in the fruit is below the limit indicated as sufficient, respiratory metabolism increases and maturation and senescence are accelerated (Pérez-Pérez $e t$ al., 2008; Soto-Parra et al., 2015). In terms of nutrition, Ca is the nutrient with the greatest effect on the storage potential and quality of apples. Therefore, there is a direct relationship between the $\mathrm{Ca}$ content of the fruit, the firmness and the shelf life (Soto et al., 2015).

There are few studies indicating the post-harvest effects of foliar fertilization with calcium carbonate and calcium sulphate in apple trees. However, physiological bases and several studies related to the application of calcium established that $\mathrm{Ca}$ nutrition in fruit trees induced higher quality of the final crop and lower fruit damage during postharvest. This has been observed in avocado, pear, strawberry, mango and apple tree (López and Cajuste, 1995). Due to the economic importance of apple growth, it is important to carry out research that develops techniques that increase both the quality and the useful life of the fruit.

Several authors have demonstrated the effect of $\mathrm{Ca}$ on the factors that influence the quality of post-harvest fruits. Bouzo and Cortez (2012) reported for melon fruits a 60\% increase in external firmness of the fruit after foliar applications of calcium nitrate. However, applications of ammonium calcium EDTA and organic calcium did not show increases in the concentration of soluble solids or fruit weight. Lanauskas et al. (2006) mentioned that foliar applications with calcium nitrate increased the sucrose content in strawberry fruits, but did not influence the content of soluble solids, total sugars and titrated acids. Davarpanah et al. (2018) upon applying foliar treatments for two seasons with nano-Ca and $\mathrm{CaCl}_{2}$ at $1 \%$ and $2 \%$ on pomegranate fruits indicated a significant decrease of the cracking of the fruit in comparison with the control treatment and an increase in the concentration of solids soluble totals of $7.6 \%$ in the second season with $\mathrm{CaCl}_{2} 1 \%$. However, for titrated acidity, fruit maturity and total sugar, no increases were recorded with any treatment. Ramezanian et al. (2009) performed foliar applications with calcium chloride in concentrations of $2 \%$ and $4 \%$, which significantly increased the average weight of the fruit and the soluble solids content in both concentrations.

In general, there is little information available on the effect of calcium carbonate and calcium sulphate on the post-harvest quality of apple, so the objectives of the present study were to evaluate the influence of foliar application of calcium carbonate and calcium sulphate on diameter, weight, color, firmness, soluble solids, titrated acidity and sugar-acidity ratio in apple fruits (Malus domestica Borkh.) cvs. 'Top Red' and 'Golden Delicious'; also, it was investigated the economical efficiency of products used in this regard, to identify products with lower cost, but better results on apple quality.

\section{Materials and Methods}

\section{Study area}

The research was carried out during the 2016 vegetative cycle in the municipality of Cuauhtémoc, Chihuahua, in the orchard "Field 22", which is located at coordinates $28^{\circ} 24^{\prime} 18^{\prime \prime}$ North $106^{\circ} 52^{\prime} 00^{\prime \prime}$ West. The climate is classified as semi-arid. The physical-chemical characteristics corresponding to the soil of the orchard under study correspond to a strongly clayey texture, $\mathrm{pH}$ in $\mathrm{CaCl}_{2} 6.58$, organic matter content $1.03 \%$, C.E. 0.15 mmhos $\mathrm{cm}^{-1}$, $\mathrm{CaCO}_{3}, 1.10 \%$, nutrients (in pp) $\mathrm{N}=\mathrm{NO}_{3} 142.5, \mathrm{P}=$ $26.60, \mathrm{~K}=87.50, \mathrm{Ca}=3112.5, \mathrm{Mg}=1537.5, \mathrm{Cu}=2.42, \mathrm{Fe}$ $=3.96, \mathrm{Mn}=3.12, \mathrm{Zn}=5.32$, percent of saturation of base cations $(\mathrm{PSBC})=31.60 \mathrm{cmol} \mathrm{kg}$, its relative distribution is $\mathrm{K} 7.08 \%, \mathrm{Ca} 49.25 \%, \mathrm{Mg} 39.88 \%$ and $\mathrm{Na} 3.78 \%$; the chemical characteristics of irrigation water are $\mathrm{pH}=7.23$, cations in meq $\mathrm{L}^{-1} \mathrm{Ca}=2.75, \mathrm{Mg}=0.75, \mathrm{Na}=0.59, \mathrm{~K}=$ 0.12 , anions in meq $\mathrm{L}^{-1} \mathrm{CO}_{3}=0.5, \mathrm{HCO}_{3}=1.28, \mathrm{SO}_{4}=$ $2.35, \mathrm{Cl}=0.08$.

\section{Orchard management and experiment design}

Apple cultivars 'Top Red'/'M111' and 'Golden Delicious'/'MM111' were planted in 1986 and 1992 respectively, with a density of 625 trees $/ \mathrm{ha}^{-1}$. The fruits were harvested on August 302016 (151 days after full flowering, DACF) and on August 242016 (145 DACF).

The study used an experimental design in randomized blocks with thirteen treatments and six repetitions per treatment. For post-harvest quality assessment, nine (9) fruits were taken at random from each of the treatments for both varieties and were stored in a controlled atmosphere for 4 months (September-December 2016) to evaluate the behavior of the products. The distribution of treatments is shown in Table 1 below.

\section{Determination of quality parameters in fruit \\ Diameter and weight of fruit}

Nine (9) fruits per repetition were used; for the diameter determination was used a vernier AutoTec, with readings in $\mathrm{mm}$ (two digits of precision), while the weight was taken with digital scale Ohaus Scout ${ }^{\mathrm{TM}}$ Pro-0 at $500.00 \mathrm{~g}$.

\section{Colour}

Two measures of colour per fruit were taken on intermediate sides, in respect to colour scales developed for 'Red Delicious' and for 'Golden Delicious' by Soto et al. (2001), using six categories: 1) green; 2) start of red striations formation; 3 ) uniform opaque red striations; 4) full red striations. In order to make the scale more objective, the colour was expressed as a percentage.

\section{Firmness}

The firmness of the pulp of the fruit was determined with penetrometer (model Effe-Gi327, 0-28 lb in ${ }^{2}$ ); two readings were taken for each fruit on the sides on which the color was measured and thus the individual average was obtained. Five representative fruits were selected from the nine taken for the sample, in which measurements were made. 
Table 1. Characteristics of the commercial presentations sources of Ca used

\begin{tabular}{|c|c|c|c|c|}
\hline Treatment & Description & Characteristics & $\begin{array}{l}\text { Application } \\
\text { concentration }^{\mathrm{x}} \\
\mathrm{Kg} / \mathrm{L} \mathrm{ha}^{-1}\end{array}$ & Coding \\
\hline 1 & Producer witness & $\begin{array}{l}4 \text { Applications NICA+4 applications META } \\
\text { (2,000 ppm de Ca) }\end{array}$ & & TESP \\
\hline 2 & Water & & 0.0 & AGUA \\
\hline 3 & Barrier & $\begin{array}{c}\text { Calcium } 10 \%, \mathrm{SiO}_{2} 24 \% \mathrm{p} / \mathrm{p} \text {, conditioners and thinners } \\
66 \% \text { (Cosmocel) }\end{array}$ & $4^{2}$ & BARR \\
\hline 4 & Calcium polyiquel & Ca 10\%, Mg 1\%, B 0.5\%, Mo 10 ppm (ArystaLifeScience) & $5^{2}$ & POCA \\
\hline 5 & Thoramin calcium & $\begin{array}{l}\text { Free amino acids 5\%, Ca 8\%, B } 0.21 \%, \mathrm{~L} \text { amino acids } 5 \% \\
\qquad \mathrm{p} / \mathrm{p} \text { (Tradecorp) }\end{array}$ & $5^{2}$ & BOCA \\
\hline 6 & Calbit C & $\mathrm{CaO} 15 \%$ p/p, 21.7\% p/v (Valagro) & $3.5^{2}$ & CALC \\
\hline 7 & Packhard & $\begin{array}{c}\text { Ca } 8 \% \text { p/p B } 0.25 \text {, acids polyhydroxycarboxylic } 6 \% \mathrm{p} / \mathrm{p} \\
\text { (total oxidizable organic carbon } 5.0 \% \text { ) } \\
\text { (Chihuahua chemical products SA de CV) }\end{array}$ & $6^{2}$ & PACK \\
\hline 8 & Calcium matalosate & Calcium $6 \%$ calcium amino acid chelate p/p (Albión) & $4^{2}$ & META \\
\hline 9 & Calcium chloride & Ca $35.74 \%$ purity $95 \%$ & 6 & CACL \\
\hline 10 & Foliar calcium & $\begin{array}{c}\text { Ca } 22.58 \%, \text { S } 18.07 \% \\
\text { (Industrial plaster of Navojoa SA de CV) }\end{array}$ & 20 & CAFO \\
\hline 11 & Calcium carbonate & Ca 35.38\% (Cemento de Chihuahua) & 20 & CACO \\
\hline 12 & Calcium nitrate & Ca $19 \%, N 15.5 \%$, purity $95 \%$ & 13.9 & NICA \\
\hline 13 & Calcium sagaquel & $\begin{array}{l}\text { Ca } 10 \%, \mathrm{Mg} 1 \% \text {, Mo } 0.001 \%, \mathrm{~B} 0.050 \% \text {, acids } \\
\text { polyhydroxycarboxylic } 6 \% \text {, natural carbohydrates } 3 \% \text {, } \\
\text { thinners and conditioners } 79.94 \% \text { (Química sagal) }\end{array}$ & 5 & SAGA \\
\hline
\end{tabular}

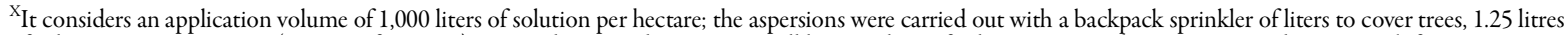
of solution per tree. Bionex (Arysta LifeScience) was used as a coadjuvant, one millilitre per litre of solution. 8 spaced sprays were made every week from June 22 to August 10 .

\section{Total soluble solids (TSS)}

The extract of two slices of each fruit was obtained (those in which the penetrometer was introduced). A refractometer (Atago $0-32^{\circ} \mathrm{Brix}$ ) previously calibrated with distilled water was used to determine TSS.

Titratable acidity

Ten (10) $\mathrm{ml}$ of the juice extract was labelled. Five (5) drops of phenolphthalein $(0.5 \mathrm{~g}$ of phenolphthalein plus 70 $\mathrm{ml}$ of ethyl alcohol and distilled water was added to total a volume of $100 \mathrm{ml}$, bearing a solution of $0.1 \mathrm{~N}$ of $\mathrm{NaOH}$ (2.15 g NaOH 97\% purity, $500 \mathrm{ml}$ of volume) until a pink brick-red purple color was obtained; the volume used was transformed into malic acid using the expression:

$\%$ malic acid $\left.\left.=\left[\left(0.1^{*} \mathrm{ml}\right) / 10\right)^{*} 67\right) / 10\right]$

Sugar acidity ratio was expressed as parts of sugar by an acid (TSS/titrated acidity).

\section{Results and Discussion}

'Top Red'

The quality of a fresh fruit is related to its physical characteristics (color, firmness, size, etc.) and its chemical composition, which determines its characteristic taste (Mancera-López et al., 2007; Soto et al., 2016). According to Mancera-López et al. (2007), the highest quality of the fruit is reached at harvest time, after which point it is not possible to increase the quality of decisive parameters. The current investigation showed significant differences due to the application of commercial sources of calcium (Table 2). For fruit size, calcium carbonate treated trees had a significantly higher fruit diameter and weight in relation to the control group at $6 \%$ and $11.2 \%$ respectively. For foliar calcium $\left(\mathrm{CaSO}_{4}\right)$, both diameter and weight of fruit were lower compared to $\mathrm{CaCO}_{3}$ by $4.3 \%$ and $10.1 \%$ correspondingly. Both sources have similar $\mathrm{Ca}$ content (35\%), however, the cost per kilogram of $\mathrm{CaSO}_{4}$ is 37.5 times higher than $\mathrm{CaCO}_{3}$. This opens up the possibility of improving the apple quality at a significantly lower cost, even representing an advantage for a greater contribution of $\mathrm{Ca}$, since calcium chloride applied to concentrations greater than $19 \mathrm{~kg}$ per $1,000 \mathrm{~L}^{-1}$ water causes burns to the foliage. This is often overlooked because the objective is to supply the largest amount of $\mathrm{Ca}$ and at pre-harvest, the damage is considered irrelevant. However, if the applications are from flowering, small and medium fruit, damage to the foliage may be considerable because at least eight (8) foliar aspersions are required (Soto et al., 2016).

Among the most important aspects of apple quality for consumers is firmness, a key attribute and driver of the acceptance by consumers of apples, many of which expect a high turgor and firmness appropriate to the purchase (Bonany et al., 2013; Cárdenas-Pérez et al., 2017). This characteristic represents the maturity of the fruit and it can indicate the useful life, freshness, durability and quality of the fruit (Cárdenas-Pérez et al., 2017), allowing on some occasions prediction of the buyers response (Jha et al., 2010; Cárdenas-Pérez et al., 2017). 
Arana et al. (2001) indicated that there is a correlation between the degree of firmness of the pulp and the time of cold storage, with 'Top Red' variety showing the greatest intensity in this relationship and 'Golden Delicious' the least intensity relative to the ratio. Therefore, the first variety is more likely to develop a good firmness. These authors also point to the existence of a relationship between firmness and maximum impact resistance, as well as the maximum and permanent deformations and duration of the impact.

By the year 2018 firmness in 'Top Red' average was 12.2 $\mathrm{lb}$ in $^{2}$, almost $30 \%$ lower than the year 2017, which also has a relationship with the sudden appearance (intensity of about $40 \%$ ) of the physiological disorder heart of water (water core), associated with an imbalance in the calcium content. It is worth mentioning that the problem presented in current experiment was shown to be less severe $(<5 \%)$ in trees subject to experimentation with calcium sources application.

The highest firmness was recorded with the foliar calcium treatment, trees bearing fruits with $16.5 \mathrm{lb} \mathrm{in}^{2}$, being higher than the control (4.24\%). Therefore these fruits can be classified as good quality apples according to Flores et al. (2018) and Silveira et al. (2007), as these latter authors recommended values from 75 to $80 \mathrm{~N}$ for pulp firmness at harvest time in red apples. Likewise, the current data matches those reported by Flores et al. (2018) in 'Top Red' apples mentioning an increase in firmness of 23\% $(73.84 \mathrm{~N})$ with respect to the witness in fruits treated with Ca. Similar results were obtained by Romero-Gomezcaña $e t$ al. (2006) in mangoes, as they indicated greater firmness in CA-treated fruits (10 and $\left.20 \mathrm{~g} \mathrm{Ca} \mathrm{L}^{-1}\right)$ compared to the control group (34\% more).

The loss of firmness, essentially in climacteric storage fruits, according to Cárdenas-Pérez et al. (2017), is due to the depolymerization of the polysaccharides of the cell wall by a variety of hydrolytic enzymes which in turn are altered by the presence of Ca, for which Romero-Gomezcaña et al. (2006) referred that senescence depends on the level of Ca in the tissues, and that due to the increase in levels of this element, parameters such as respiration, protein content and membrane fluidity are altered. These assertions, together with the results presented in hereby research, aim to be able to attribute the changes of firmness in fruit with the amount of $\mathrm{Ca}$ present, because this element is a structural constituent of the medium sheet, the walls and cell membranes and, in addition, participates in cell division and extension, influences the compartmentalization of the cell, modulates the action of hormones and signals, stabilizes the wall and membranes, and contributes to the ion equilibrium of the cell (Díaz et al., 2007).

The processing of fresh cut apples requires overcoming factors that decrease the quality of the apple, such as the rapid enzymatic patching of the tissue during transport and storage, thus in recent years different methods for its control have been studied. These include the application of different products based on $\mathrm{Ca}$ (Rodríguez et al., 2013).

One of the quality parameters for apple is color, taking into account that each variety of commercial apple requirements are specific to the color of skin; currently, apples are marketable only if they meet strict standards for the percentage of coverage and intensity of the red color, thus encouraging producers to select redder varieties despite the fact that this color is not an indicator of quality or ripeness of the fruit (Seipel et al., 2009).

In the current color determination study, $\mathrm{CaCl}$ treated trees obtained fruit within the best result, with $11.6 \%$ higher than the control group. For 'Top Red', a minimum value of $66 \%$ is recommended, corresponding to obvious dark red striations (Soto et al., 2016). Flores et al. (2018) present similar results, indicating for 'Top Red' an average of $67.6 \%$ in fruits treated with $\mathrm{Ca}$, surpassing the control group. Therefore, the fruits evaluated in this research, as well as those reported by these authors, and as dictated by the official Mexican norm (2003), would be of first quality, since it indicate $50 \%$ for bicolored or partially red cultivars. However, if we base our study on the color classification according to the criteria of the European standard for bicolor varieties (FFV-01, 1996) mentioned by Seipel et al. (2009), the fruits obtained hereby would fall within the Extra classification (more than $50 \%$ of the red surface).

For other authors, treatments with $\mathrm{Ca}$ in various fruits were not encouraging. An example was reported by Contreras-Angulo et al. (2011) in tomato fruit as they found no differences with respect to treatments with sources of $\mathrm{Ca}$ and the control group in regards to color, titratable acidity and soluble solids. Likewise, García and Cárdenas (2010) mentioned having found darkening in strawberry fruits, which they attributed, among other things, to the degradation of anthocyanins due to the application of the $\mathrm{CaCl}_{2}$ solution.

From an industrial point of view, it is also important that fruits are harvested in the optimal state of maturity, defined as the moment when they present the appropriate chemical composition, responsible for their nutritional and organoleptic characteristics, as well as the characteristics of their derivatives, for which Silveira et al. (2007) recommended optimal values for harvest of red apple variety SST greater than $11^{\circ}$ Brix and AT between 3.7 and 5.2 $\mathrm{cmol}-\mathrm{L}^{-1}$, as apples with values higher than $4.5 \mathrm{cmol} \cdot \mathrm{L}^{-1}$ are considered acidic and apples with lower values are considered sweet. For these considerations, the current BARR experiment presented the highest amount of sugar with $13.4^{\circ}$ Brix, CECO and CAFO with $12.3^{\circ}$ Brix and $12.6^{\circ} \mathrm{Brix}$, respectively, being optimal because high values of Brix degrees are undesirable.

With respect to malic acid, the best treatment was CACL with $16.8 \%$, CECO and CAFO obtained $3.9 \%$ and $6 \%$ respectively, resulting in a sugar acidity ratio greater than $40 \%$, that is considered as incipient maturity, which although mitigated by a relatively crispier fruit (greater firmness), this variety continues the transformation of starch to sugar (Mancera-Lopéz et al., 2007). A balance different from the present calcium nitrate with the lowest firmness $\left(14.6 \mathrm{lb}\right.$ in $\left.^{2}\right)$ and greater titratable acidity $(0.343 \%$ of malic acid), giving a relationship of sugar to acidity of 37.7 (with a sugar content of $12.8^{\circ} \mathrm{Brix}$, required to harvest a minimum of $12{ }^{\circ} \mathrm{Brix}$ ) (NMX-FF-061-SCFI-2003). $\mathrm{CaCO}_{3}$ presented an intermediate situation between these two contrasts, with a firmness of $10.5 \mathrm{lb} \mathrm{in}^{2}, 12.3{ }^{\circ} \mathrm{Brix}$, $0.340 \%$ malic acid and a sugar acidity ratio of 36.1 .

The values of the ratio of sugar acid (sugar ${ }^{\circ} \mathrm{Brix} /$ acidity of malic acid) proposed are less than those reported by Hammett (1980) for red cultivates, as they indicate that 
1140

these have an excellent quality of storage if the relationship of solid soluble/titratable acidity is from 32 to 36 postharvest; with a value of less than 32 the fruits have a high water loss during storage, the tendency to develop a bitter pit and problems of scalding; with a ratio of solid soluble/titratable acidity increased to 50 , the fruits should not be stored for long periods of time because of the major changes in the textural properties, whereas a solid soluble/a titratable acidity ratio of 35 to 40 is suitable for immediate sale or for short storage.

Romero-Gomezcaña et al. (2006) when determining the ${ }^{\circ}$ Brix/acidity ratio in mango, noted that no significant differences were detected between treatments with $\mathrm{Ca}$ and the control group. However, the relative difference between the control and the highest dose of $\mathrm{Ca}\left(20 \mathrm{~g} \mathrm{~L}^{-1}\right)$ was $55 \%$ in favor of the first. They also observed that the ${ }^{\circ} \mathrm{Brix} /$ acidity ratio tended to decrease as the dose of $\mathrm{Ca}$ increased. Therefore, they showed that there was an effect of the $\mathrm{Ca}$ on the delay in maturation, allowing the fruits to retain more acidity. Akthar et al. (2010), when studying the effect of $\mathrm{CaCl}_{2}$ on quality parameters in Eriobotrya japonica Lindl., found positive effects compared to the control group, as well as for firmness, whereas they noticed an increase in $\mathrm{CaCl}_{2}$ to $3 \%$ up to ten weeks, a fact that they attributed to an accumulation of this element in the cell walls, which lead to a facilitation in the reticulation of the pectic polymers, increasing the resistance of the wall and cell cohesion. For OSH they obtained the maximum concentration with $\mathrm{CaCl}_{2}$ at $3 \%\left(13.1^{\circ} \mathrm{Brix}\right)$. A fact they mentioned may be due to a higher concentration of $\mathrm{CaCl}_{2}$ (3\%) that formed a thin layer on the surface of the fruit that delayed the degradation process.

The present results are in agreement with the conclusions of these authors, in regard with the positive effect on firmness and $\mathrm{OSH}$ in fruits from Ca sources. In the same context, Ranjbar et al. (2018) mentioned finding greater firmness in Ca-treated fruits, as well as for AT where Ca-treated fruits turned out to have higher values compared to the control group, with $2.5 \%$ the maximum found. These same authors showed a decrease in the percent of AT during storage, which however was lower with the treatment of $\mathrm{Ca}$, this may be due to a decrease in the rate of softening during the climacteric period, which affects the system of glycolytic enzymes and leads to the preservation of the acids. However, the same was not true for OSH, as in the control group fruit $\mathrm{OSH}$ was greater than in fruit treated with $\mathrm{Ca}$ sources. Similar results were reported by Torres et al. (2017) finding a decrease in $\mathrm{OSH}$ in apple fruits treated with $\mathrm{Ca}$.

If we consider the statistical responses obtained in $\mathrm{OSH}$, titrated acidity and acidity sugar ratio, the inclusive and representative variable would therefore be the acidity sugar ratio. Wang et al. (2010) reported the sugar/acid ratio as a variable associated with apple fruit taste, which tends to increase with the maturation progresses, due to the decrease in the malic acid content that is used as a respiratory substrate, to the increase in the sugar content due to the hydrolysis of starch accumulated during growth. If we establish an optimal range of full flavor of the variety with storage capacity and shelf capacity between 30 and 40, then, the best quality was presented by $\mathrm{CaSO}_{4}, \mathrm{CaCO}_{3}, \mathrm{CaCl}$ and control, respectively; the four sources of calcium exceeded the control producer, which reinforces its impact since it is considered that this orchard received a highly technical intensive management with infrastructure and equipment that places it at low risk and with high responsiveness to abiotic and biotic contingencies. Such a result gives perspective to the use of $\mathrm{CaCO}_{3}$ as an alternative calcium foliar supplement to improve apple quality. The critical test

Table 2. Post-harvest apple quality for 'Top Red' cv. under different commercial sources of calcium and foliar spray

\begin{tabular}{|c|c|c|c|c|c|c|c|c|}
\hline \multicolumn{5}{|c|}{ Fruit finish } & \multicolumn{4}{|c|}{ Maturity of the fruit } \\
\hline \multirow{2}{*}{\multicolumn{2}{|c|}{$\begin{array}{l}\text { Product/ concentration ha } \mathrm{a}^{-1} \\
\qquad \mathrm{~L}^{\mathrm{z}} / \mathrm{kg}\end{array}$}} & \multirow{2}{*}{$\begin{array}{c}\text { Diameter } \\
\mathrm{cm}\end{array}$} & \multirow{2}{*}{$\begin{array}{c}\text { Weight } \\
\mathrm{g}\end{array}$} & \multirow{2}{*}{$\begin{array}{c}\text { Colour } \\
\%\end{array}$} & \multirow{2}{*}{$\begin{array}{c}\text { Firmess } \\
\mathrm{lb}^{\mathrm{bin}}{ }^{2}\end{array}$} & \multirow{2}{*}{$\begin{array}{l}\text { TSS } \\
{ }^{\circ} \text { Brix }\end{array}$} & \multirow{2}{*}{$\begin{array}{c}\text { Acidity } \\
\% \text { Ac. Malic }\end{array}$} & \multirow{2}{*}{ TSS/Titratable acidity } \\
\hline & & & & & & & & \\
\hline & & $0.0455^{\mathrm{U}}$ & 0.0599 & 0.08296 & $<.0001$ & 0.0034 & 0.1019 & 0.0244 \\
\hline $\begin{array}{l}\text { Producer } \\
\text { witness }\end{array}$ & 0.0 & $70.7 \quad \mathrm{~d}$ & $163.0 \mathrm{bcd}$ & $67.22 \mathrm{~b}$ & $15.8 \mathrm{ab}$ & $13.10 \mathrm{a}$ & $0.333 \mathrm{bcd}$ & $40.53 \mathrm{a}$ \\
\hline Water & 0.0 & $74.2 \mathrm{abc}$ & $178.36 \mathrm{abc}$ & $76.50 \mathrm{a}$ & $12.74 \mathrm{de}$ & $12.55 \mathrm{abc}$ & $0.320 \mathrm{~cd}$ & $38.62 \mathrm{abcd}$ \\
\hline Barrier & $4^{z}$ & $74.1 \mathrm{abc}$ & $179.80 \mathrm{ab}$ & $72.95 \mathrm{ab}$ & 13.0de & $13.40 \mathrm{a}$ & $0.334 \mathrm{bcd}$ & $40.18 \mathrm{ab}$ \\
\hline $\begin{array}{l}\text { Calcium } \\
\text { polyiquel }\end{array}$ & $5^{2}$ & $71.4 \mathrm{~cd}$ & $167.0 \mathrm{abcd}$ & $70.99 \mathrm{ab}$ & $12.2 \mathrm{e}$ & $12.96 \mathrm{ab}$ & $0.323 \mathrm{~cd}$ & $39.41 \mathrm{abc}$ \\
\hline $\begin{array}{l}\text { Calcium } \\
\text { boramin }\end{array}$ & $5^{2}$ & $71.8 \mathrm{bcd}$ & $159.27 \mathrm{~d}$ & $73.63 \mathrm{ab}$ & $12.09 \mathrm{e}$ & $12.81 \mathrm{ab}$ & $0.333 \mathrm{~cd}$ & $39.47 \mathrm{abc}$ \\
\hline Calbit C & $3.5^{2}$ & $72.9 \mathrm{abcd}$ & $17.17 \mathrm{abcd}$ & $75.51 \mathrm{a}$ & $11.5 \mathrm{ab}$ & $12.43 \mathrm{bc}$ & $0.315 \mathrm{~d}$ & $39.66 \mathrm{abc}$ \\
\hline Packhard & $6^{2}$ & $71.5 \mathrm{~cd}$ & $159.77 \mathrm{~d}$ & $67.12 \mathrm{~b}$ & $14.0 \mathrm{~cd}$ & $13.03 \mathrm{ab}$ & $0.375 \mathrm{ab}$ & $35.40 \mathrm{bcd}$ \\
\hline $\begin{array}{l}\text { Calcium } \\
\text { matalosate }\end{array}$ & $4^{z}$ & $74.5 \mathrm{ab}$ & $176.65 \mathrm{abcd}$ & $73.77 \mathrm{ab}$ & $13.0 \mathrm{de}$ & $11.86 \mathrm{~cd}$ & $0.351 \mathrm{abcd}$ & $34.01 \quad \mathrm{~d}$ \\
\hline $\begin{array}{l}\text { Calcium } \\
\text { chloride }\end{array}$ & 6 & $73.2 \mathrm{abcd}$ & $171.39 \mathrm{abcd}$ & $74.95 \mathrm{a}$ & $12.17 \mathrm{e}$ & $12.50 \mathrm{abc}$ & $0.389 \mathrm{a}$ & $33.74 \quad \mathrm{~d}$ \\
\hline Foliar calcium & 20 & $71.89 \mathrm{bcd}$ & $161.15 \mathrm{~cd}$ & $67.15 \mathrm{~b}$ & $16.50 \mathrm{a}$ & $12.61 \mathrm{abc}$ & $0.363 \mathrm{abc}$ & $35.16 \mathrm{~cd}$ \\
\hline $\begin{array}{l}\text { Calcium } \\
\text { carbonate }\end{array}$ & 20 & $74.8 \mathrm{a}$ & $181.40 \mathrm{a}$ & $70.60 \mathrm{ab}$ & $15.0 \mathrm{bc}$ & $12.26 \mathrm{bcd}$ & $0.340 \mathrm{abcd}$ & $36.11 \mathrm{abcd}$ \\
\hline $\begin{array}{l}\text { Calcium } \\
\text { nitrate }\end{array}$ & 13.9 & $74.4 \mathrm{ab}$ & $171.8 \mathrm{ab}$ & $69.21 \mathrm{ab}$ & $14.55 \mathrm{~b}$ & $12.78 \mathrm{ab}$ & $0.343 \mathrm{abcd}$ & $37.70 \mathrm{abcd}$ \\
\hline $\begin{array}{l}\text { Calcium } \\
\text { sagaquel }\end{array}$ & $5^{2}$ & $73.9 \mathrm{abc}$ & $179.22 \mathrm{ab}$ & $76.16 \mathrm{a}$ & $15.67 \mathrm{ab}$ & $11.36 \mathrm{~d}$ & $0.338 \mathrm{abcd}$ & $33.66 \mathrm{~d}$ \\
\hline & DMSW & 2.9 & 17.6 & 7.51 & 1.33 & 0.90 & 0.031 & 5.0006 \\
\hline & $\mathrm{CV}^{\mathrm{x}}$ & 3.39 & 8.90 & 9.035508 & 8.27 & 6.19 & 10.66 & 11.64 \\
\hline & $\mu^{Y}$ & 73.0 & 171.4 & 71.98628 & 13.94 & 12.6 & 0.343 & 37.21 \\
\hline
\end{tabular}

"Probability $\operatorname{Pr} \geq 0.05$ not significant, $0.05 \leq \operatorname{Pr} \leq 0.01$ significant, $\operatorname{Pr}<0.01$ highly significant; ${ }^{\vee}$ Different letters are statistically different according to the t-Student multiple-range test $\alpha 0.05$; ${ }^{\mathrm{W}}$ Minimum significant difference (t-Student $\left.\alpha 0.05\right)$; ${ }^{\mathrm{X}}$ Variable coefficient; ${ }^{\mathrm{Y}}$ Media general. 
will be the behavior in storage because a quantity of fruit equal to that harvested in the controlled atmosphere is to be stored and further analysed.

\section{'Golden Delicious'}

'Golden Delicious' is marketed after a period of frigoconservation and the minimization of marketable apple losses (which can reach up to $40 \%$ of erosion) (Sió et al., 2018). This variety of apple preserved in a controlled atmosphere $(\mathrm{AC})$, suffers the most important changes during the first four months of conservation, with a significant loss of quality (Guerra and Casquero, 2005) which is reflected in: decrease of firmness, changes in color, hydrolysis of starch and increase of sugars, whose evolution, combined with the effect of various deterioration factors, define the storage life (Cepeda et al., 2014). Sió et al. (2018) mentioned that a high concentration of $\mathrm{Ca}$ in fruits prevents numerous pre-and post-harvest disorders from developing.

From this perspective, the results presented with respect to CA foliar applications for the 'Golden Delicious' variety (Table 3) indicate that treatment with foliar calcium, which recorded significantly the largest diameter and fruit weight at $67.2 \mathrm{~cm}$ and $141.5 \mathrm{~g}$ respectively, showed a low firmness $\left(10.70 \mathrm{lb} \mathrm{in}^{2}\right)$ compared to the range recommended by Cepeda et al. (2014) for both harvest $(74-75 \mathrm{~N})$ and maturity of consumption (54-55 N) in this variety. The same authors mentioned having obtained the greatest firmness in apple fruits treated with pre-and post-harvest $\mathrm{CaCl}_{2}$ sources (pre-harvest spraying with $4 \% \mathrm{CaCl}_{2}$ and immersions in $6 \% \mathrm{CaCl}_{2}$ solutions). However, in the current research the treatment with this same Ca source, did not positioned outstanding, since the fruit maintained a $6.92 \%$ level, lower than that of the control group, which achieved the best firmness (11.98 $\left.\mathrm{lb} \mathrm{in}^{2}\right)$, followed by Packhard (11.95). Data concerning the size and weight of apple fruit reported by Flores et al. (2018) point out that, indeed, $\mathrm{CaCO}_{3}$ treatments tend to increase these variables indicating $5.2 \%$ and $13.4 \%$ increases over the control.

For the evaluation of color, $\mathrm{CaSO}_{4}$ presented the highest percentage with regard to all treatments, with $60.87 \%$, as well as the highest amount of sugar $\left(13.95^{\circ} \mathrm{Brix}\right)$, followed by $\mathrm{CaCl}_{2}$ with $60.49 \%$ and $13.96^{\circ} \mathrm{Brix}$, respectively, found in the acceptable range for the amount of sugar, since higher amounts are disregarded for their conservation, so that the values obtained fall within what Soto et al. (2015) indicated as ideal for harvest $\left(13^{\circ} \mathrm{Brix}\right)$.

The same two treatments presented AT values of $0.482 \%$ and $0.538 \%$ malic acid and acidity sugar ratio of 29.01 and 26.66 correspondingly. Following the recommended data presented by Soto et al. (2015)as ideal for harvest quality in the 'Golden Delicious' variety, the hereby results for titrated acidity are considered low, because they indicate $0.7 \%$ malic acid, not enough to maintain a juicy, crispy apple, figure that does not allow the expression of sugar to achieve the characteristic flavor of the variety.
Finally Soto et al. (2015) point out that in order to obtain a full taste of the variety, storage capacity and considerable shelf life, an acidity sugar ratio of 22.0 is required. This is inferior to the current results, but high enough to reach the recommended level by Cepeda et al. (2014) for cooling purposes in normal or controlled atmosphere (33.1). However, the sugar/acid ratio has to increase as the fruit matures, due to the decrease in the malic acid content used as a respiratory substrate and the increase in the sugar content due to the hydrolysis of starch accumulated during growth (Cepeda et al., 2014; Soto et al., 2015).

Soto et al. (2016) mentioned the evolution of color after harvest in 'Golden Delicious' as a very particular feature, as in varieties such as 'Top Red' this does not happen, its harvest color remaining until the end. For 'Golden Delicious' in harvest they indicate an optimal fruit color of 45 to $50 \%$, corresponding to transition from rough green coarse crimson-waxy green, which confers a fresh appearance that must be associated with a good amount of sugar and sugar-acidity balance suitable for the fruit to be of pleasant taste post-harvest. Referring to the optimal coloring for post-harvest, they consider values ranging from $56 \%$ to $66 \%$ (advanced waxy green) which denotes freshness and corresponds to an attractive maturity for the buyer (not very green - immaturity, nor very yellow - over maturity).

The results obtained in the present research indicate that by using foliar calcium in this variety, it is possible to obtain the best coloration for post-harvest by then inciting the preference for the consumer and decreasing the erosion. Also, for the variety 'Granny Smith', Rodríguez et al. (2013) point out, with regard to the evaluation of the browning of the apple, a lesser development of darkening within the treatment with higher percent in $\mathrm{Ca}(1.0 \%$ ÀC $+1,0 \grave{\mathrm{A} A}$ $0.5 \%$ calcium chloride). Therefore, this treatment maintained the highest values for the greenish shade characteristic of this variety, by which they infer that the treatment with the highest percent of calcium is effective to reduce the deterioration of the 'Granny Smith' apples, maintaining quality during storage.

In terms of the amount of calcium per application of $\mathrm{CaCO}_{3}, 7,000$ ppm-without fruit or foliage damage -was provided, which represent 1,300 times more than calcium boramin and Packard and twice the amount for calcium metalosate. On the other hand, it is very likely that the intensity of the responses obtained with foliar aspersions can be improved through the concurrent use of carbonate applications to the soil, which in itself means a watershed in the integral calcium supplement for the apple tree.

From this perspective, analysing Table 4 one can observe the economic cost of commercial calcium products applied during the project, as well as the price comparison between the same products, resulting with the lowest costs belonging to calcium carbonate and foliar calcium, with the first even more economical by $\$ 2.5$ compared to the second. However the decision on which product to use depends on the apple 
1142

Table 3. 'Golden Delicious' apple harvest quality under different commercial sources of calcium in foliar spray

\begin{tabular}{|c|c|c|c|c|c|c|c|c|}
\hline \multirow{2}{*}{\multicolumn{2}{|c|}{$\frac{\text { Fruit finish }}{\text { Product/ concentration }}$}} & \multicolumn{2}{|c|}{ Maturity of the fruit } & \multicolumn{5}{|c|}{ Fruit finish } \\
\hline & & Diameter & Weight & Colour & Firmness & TSS & Acidity & TSS/Titratable \\
\hline \multicolumn{2}{|c|}{$h a^{-1} L^{Z} / k g$} & $\mathrm{~cm}$ & $\mathrm{~g}$ & $\%$ & $1 \mathrm{~b}$ in $^{2}$ & ${ }^{\circ}$ Brix & $\%$ Ac. Malic & acidity \\
\hline & & 0.1518 & 0.2950 & 0.7840 & 0.1538 & 0.0470 & 0.2339 & 0.0529 \\
\hline $\begin{array}{l}\text { Producer } \\
\text { witness }\end{array}$ & 0.0 & 64.57 & $122.0 \mathrm{~b}$ & $58.61 \mathrm{a}$ & $11.98 \mathrm{a}$ & $13.18 \mathrm{abcd}$ & $0.431 \mathrm{c}$ & $31.15 \mathrm{a}$ \\
\hline Water & 0.0 & 66.65 & $132.94 \mathrm{ab}$ & 58.09 a & $11.60 \mathrm{ab}$ & $13.43 \mathrm{abc}$ & $0.447 \mathrm{bc}$ & $30.42 \mathrm{ab}$ \\
\hline Barrier & $4^{2}$ & 66.41 & $131.45 \mathrm{ab}$ & $57.88 \mathrm{a}$ & $11.55 \mathrm{ab}$ & $13.77 \mathrm{ab}$ & $0.471 \mathrm{abc}$ & $29.65 \mathrm{abc}$ \\
\hline $\begin{array}{l}\text { Calcium } \\
\text { polyiquel }\end{array}$ & $5^{z}$ & 64.22 & $118.25 \mathrm{~b}$ & $58.55 \mathrm{a}$ & $10.67 \mathrm{abc}$ & $12.30 \mathrm{~d}$ & $0.442 \mathrm{c}$ & $27.97 \mathrm{abcd}$ \\
\hline $\begin{array}{l}\text { Calcium } \\
\text { boramin }\end{array}$ & $5^{2}$ & 66.41 & $134.60 \mathrm{ab}$ & $58.57 \mathrm{a}$ & $10.33 \mathrm{bc}$ & $12.80 \mathrm{bcd}$ & $0.485 \mathrm{abc}$ & $26.96 \mathrm{abcd}$ \\
\hline Calbit C & $3.5^{\mathrm{z}}$ & 63.67 & $122.34 \mathrm{~b}$ & $57.93 \mathrm{a}$ & $11.07 \mathrm{abc}$ & $13.33 \mathrm{abcd}$ & $0.467 \mathrm{abc}$ & $28.70 \mathrm{abcd}$ \\
\hline Packhard & $6^{2}$ & 62.91 & $117.51 \mathrm{~b}$ & $60.02 \mathrm{a}$ & $11.95 \mathrm{abc}$ & $13.33 \mathrm{abcd}$ & $0.453 \mathrm{bc}$ & $29.73 \mathrm{abc}$ \\
\hline $\begin{array}{l}\text { Calcium } \\
\text { matalosate }\end{array}$ & $4^{2}$ & 63.69 & $119.50 \mathrm{~b}$ & $57.65 \mathrm{a}$ & $9.87 \mathrm{c}$ & $13.51 \mathrm{abc}$ & $0.505 \mathrm{abc}$ & $27.56 \mathrm{abcd}$ \\
\hline $\begin{array}{l}\text { Calcium } \\
\text { chloride }\end{array}$ & 6 & $65.20 \mathrm{abcd}$ & $130.01 \mathrm{ab}$ & $60.49 \mathrm{a}$ & $11.15 \mathrm{abc}$ & $13.96 \mathrm{a}$ & $0.538 \mathrm{a}$ & $26.66 \mathrm{~cd}$ \\
\hline $\begin{array}{l}\text { Foliar } \\
\text { calcium }\end{array}$ & 20 & $67.22 \mathrm{a}$ & $141.45 \mathrm{a}$ & $60.87 \mathrm{a}$ & $10.70 \mathrm{abc}$ & $13.95 \mathrm{a}$ & $0.482 \mathrm{abc}$ & $29.01 \mathrm{abc}$ \\
\hline $\begin{array}{l}\text { Calcium } \\
\text { carbonate }\end{array}$ & 20 & 64.07abcd & $125.08 \mathrm{ab}$ & $57.80 \mathrm{a}$ & $10.05 \mathrm{c}$ & $12.93 \mathrm{abcd}$ & $0.493 \mathrm{abc}$ & $26.25 \mathrm{~cd}$ \\
\hline $\begin{array}{l}\text { Calcium } \\
\text { nitrate }\end{array}$ & 13.9 & 65.66abcd & $132.15 \mathrm{ab}$ & $57.61 \mathrm{a}$ & $10.80 \mathrm{abc}$ & $12.90 \mathrm{bcd}$ & $0.527 \mathrm{ab}$ & 25.21 \\
\hline \multirow[t]{4}{*}{$\begin{array}{l}\text { Calcium } \\
\text { sagaquel }\end{array}$} & $5^{z}$ & $63.19 \mathrm{~cd}$ & $122.26 \mathrm{~b}$ & $57.66 \mathrm{a}$ & $11.28 \mathrm{abc}$ & $12.56 \mathrm{~cd}$ & $0.465 \mathrm{abc}$ & $27.19 \mathrm{bcd}$ \\
\hline & $\mathrm{DMS}^{\mathrm{W}}$ & 3.32 & 18.94 & 3.95 & 1.42 & 1.046 & 0.071 & 3.61 \\
\hline & $\mathrm{CV}^{\mathrm{X}}$ & 4.44 & 12.92 & 5.84 & 11.30 & 6.85 & 12.94 & 11.10 \\
\hline & $\mu^{Y}$ & 64.92 & 126.89 & 58.59 & 11.92 & 13.23 & 0.47 & 28.19 \\
\hline
\end{tabular}

${ }^{\mathrm{U}}$ Probability $\operatorname{Pr} \geq 0.05$ not significant, $0.05 \leq \operatorname{Pr} \leq 0.01$ significant, $\operatorname{Pr}<0.01$ highly significant; ${ }^{\mathrm{V}}$ Different letters are statistically different according to the $\mathrm{t}-\mathrm{Student}$ multiple-range test $\alpha 0.05$; ${ }^{\mathrm{W}}$ Minimum significant difference (t-Student $\left.\alpha 0.05\right) ;{ }^{\mathrm{X}}$ Variable coefficient; ${ }^{\mathrm{Y}}$ Media general.

Table 4. Economic aspects based on foliar applications of calcium

\begin{tabular}{|c|c|c|c|c|}
\hline Product & Cost & Concentration by application & Cost per application & Total for 8 applications \\
\hline BARR & $\$ 75.00$ & 4 & $\$ 300$ & $\$ 2400$ \\
\hline POCA & 83.00 & 5 & 415 & 3,320 \\
\hline BOCA & 101.00 & 5 & 505 & 4,040 \\
\hline CALC & 141.00 & 3.5 & 493.50 & 3,948 \\
\hline PACK & 117.00 & 6 & 702 & 5,616 \\
\hline META & 282.40 & 4 & 1129.60 & $9,036.80$ \\
\hline CACL & 14.72 & 6 & 88.32 & 706.56 \\
\hline CAFO & 4 & 20 & 80 & 640 \\
\hline $\mathrm{CACO}$ & 1.5 & 20 & 30 & 240 \\
\hline NICA & 10.52 & 13.85 & 145.70 & $1,165.62$ \\
\hline SAGA & 60 & 5 & 300 & 2400 \\
\hline
\end{tabular}

variety, because calcium carbonate induce the best response for the 'Top Red' variety, while foliar calcium produced in almost all variables analysed the best response for 'Golden Delicious' variety.

\section{Conclusions}

Both calcium carbonate and foliar calcium are a favorable alternative to improve the quality of apples fruit during post-harvest, at a considerably low cost compared to other calcium presentations for routine use. Calcium carbonate favors the increase in quality variables such as diameter, weight, color and titrated acidity in the variety 'Top Red' and foliar calcium increased diameter, weight, color, total soluble solids, titrated acidity and acidity ratio in 'Golden Delicious'. Finally, it is worth to emphasize that the foliar application of both calcium carbonate and foliar calcium can be considered an appropriate agronomic 
practice to improve the post-harvest quality of 'Top Red' and 'Golden Delicious' apples, while reducing the amounts invested on fertilization. For this reason, the tested $\mathrm{Ca}$ sources can be considered as a good alternative of foliar calcium supplement applied in order to preserve the quality of the apple during post-harvest.

\section{Conflict of Interest}

The authors declare that there are no conflicts of interest related to this article.

\section{References}

Arana JI, Jarèn C, Arana A, Arazuri S (2001). Pruebas diagnósticas en la clasificación de productos agrícolas [Diagnostic tests in the production of agricultural crops]. Horticultura Revista de Industria, Distribución Y Socioeconomía Hortícola: Frutas, Hortalizas, Flores, Plantas, Árboles Ornamentalesy Viveros 152:20-26.

Akhtar A, Abbasi NA, Hussain A (2010). Effect of calcium chloride treatments on quality characteristics of loquat fruit during storage. Pakistan Journal Botany 42(1):181-188.

Bonany J, Buehler A, CarbóJ, Codarin S, Donati F, Echeverria G, ... Schoorl $F$ (2013). Consumer eating quality acceptance of new apple varieties in different European countries. Food Quality and Preference 30(2):250259.

Bouzo CA, Cortez SB (2012). Efecto de la aplicación foliar de calcio sobre algunos atributos de calidad en frutos de melón [Effect of foliar application of calcium on some quality attributes in melon fruits]. Revista de Investigaciones Agropecuarias 38(3):257-262.

Cárdenas-Pérez S, Méndez-Méndez JV, Chanona-Pérez JJ, Zdunek A, Güemes-Vera N, Calderón-Domínguez G, Rodríguez-González F (2017). Prediction of the nanomechanical properties of apple tissue during its ripening process from its firmness, color and microstructural parameters. Innovative Food Science and Emerging Technologies 39:79-87.

Castellano G, Quijada O, Camacho R (2005). Fertilización precosecha con fuentes de calcio sobre la firmeza y calidad de frutas de guayaba (Psidium guajava L.) [Pre-harvest fertilization with calcium sources on the firmness and quality of guava fruits (Psidium guajava L.)]. Revista Iberoamericana de Tecnología Postcosecha 6(2):72-77.

Castellano G, Quijada O, Sindoni M, Marin C, Camacho R(2006). Efecto del calcio sobre la pudrición apical en frutos de guayaba (Psidium guajava) [Effect of calcium on stylar end rot control in guava (Psidium guajava) fruits]. Fitopatologia Venezuela 19(2):42-43.

Cepeda CI, Saucedo VC, Colinas LM, Rodríguez AJ (2014). Evaluación de tratamientos pre y postcosecha con $\mathrm{CaCl}_{2}$ en la frigoconservación y calidad de manzana cv. 'Golden Delicious' [Evaluation of pre and posthaverst treatments with $\mathrm{CaCl}_{2}$ in the frigoconservation and quality of Apple cv. 'Golden Delicious']. Revista Iberoamericana de Tecnología Postcosecha 15(1):5460.

Contreras-Angulo 1A, Heredia JB, Sánchez-Álvarez CE, Angulo-Escalante MA, Villarreal-Romero M (2011). Efecto del genotipo y sales de calcio en la calidad de tomates frescos cortados [Effect of genotype and calcium salts on the quality of fresh cut tomatoes]. Revista Chapingo. Serie
Horticultura 17(Sp 1):39-45.

Davarpanah S, Tehranifar A, Abadía J, Val J, Davarynejad G, Aran M, Khorassani R (2018). Foliar calcium fertilization reduces fruit cracking in pomegranate (Punica granatum cv. 'Ardestani'). Scientia Horticulturae 230:86-91.

Díaz A, Cayón G, Mira JJ (2007). Metabolismo del calcioy su relación con la "mancha de madurez" del fruto de banano. Una revisión [Calcium metabolism and its relationship with "maturity bronzing" in banana fruits. A review].Agronomía Colombiana 25(2):280-287.

Flores CM, Soto Parra JM, Salas Salazar NA, Sánchez Chávez E, Piña Ramírez FJ (2018). Efecto del subproducto industrial $\mathrm{CaCO}_{3}$ en los atributos de calidad, contenido fenólico y capacidad antioxidante de manzana cvs 'Golden Delicious' y Top Red' [Effect of $\mathrm{CaCO}_{3}$ industrial byproduct on quality atributes, phenolic content and antioxidant capacity of apple cvs Golden Delicious and Top Red]. Nova Scientia 10(20):6482.

Garcia MA, Praderas CG (2010). Influencia del cloruro de cálcico y de un tipo de empaque sobre las propiedades fisicoquímicas y la textura de la fresa (Fragaria $\mathrm{x}$ ananassa Duch.) durante el almacenamiento [Influence of calcium chloride and a packing type on the physico-chemical properties and the texture of the strawberry (Fragaria x ananass $a$ Duch) during storage]. Revista Facultad Nacional Agronomia-Medellin 63(1):5417-5427.

García-Muñoz SA, Soto-Parra JM, Piña-Ramírez FJ (2015). Enmiendas de calcio para optimizar parámetros del suelo en manzano [Calcium amendments to optimize soil parameters in apple trees]. Biológico Agropecuaria Tuxpan 4(6): 11341146.

Guerra M, Casquero PA (2005). Evolución de la madurez de variedades de manzana y pera en almacenamiento frigorífico conjunto con absorbedor (2010) de etileno [Development of ripeness of apple and pear varieties in a cold storage room with an ethylene absorbent system]. Información Tecnológica 16(4):11-16.

Hammet RH (1980). Evaluation of fresh market and storage quality of North Carolina apples. North Carolina Agricultural Research Service in Cooperation with the United States Department of Agriculture. Tech Bu 262-265.

Jha SN, Narsaiah K, Sharma AD, Singh M, Bansal S, Kumar R (2010). Quality parameters of mango and potential of non-destructive techniques for their measurement - a review.Journal of Food Science and Technology $47(1): 1-14$.

Lanauskas J, Uselis N, Valiuskaite A, Viskelis P (2006). Effect of foliar and soil applied fertilizers on strawberry healthiness, yield and berry quality. Agronomy Research 4:247-250.

Lobos MT, Pinilla QH, Lobos AW (2011). Efecto de aplicaciones de calcio en la calidad de la fruta de arándano alto (Vaccinium corymbosum $\mathrm{L}$.) $\mathrm{cv}$. 'Elliot' [Effect of calcium applications on the quality of highbush blueberry fruit cv.Elliott].Idesia (Arica) 29(3):59-64.

López L, Cajuste L (1995). Efecto de las aplicaciones de diferentes fuentes de calcio en precosecha sobre la calidad de fruto de aguacate 'Fuerte' [Efect of the aplications of diferent sources of calcium]. Retrieved 2019 December 28 from http://avocadosource.com/Journals/ CICTAMEX/CICTAMEX_1995/Agroind_1_95.pdf.

Mancera-López M, Soto-Parra J, Sánchez-Chávez E, Yáñez-Muñoz R, 
1144

Montes-DomínguezF, Balandran-Quintana R(2007). Caracterización mineral de manzana 'Red Delicious' y 'Golden Delicious' de dos países productores [Mineral characterization of 'Red Delicious' and 'Golden Delicious' apple varieties from two producing countries]. Tecnociencia Chihuahua 1(2):6-17.

Mitre V, Buta E, Lukács L, Mitre I, Teodorescu R, Hoza D, Sestraș AF, Stănică F (2018). Management of apple scab and powdery mildew using bicarbonate salts and other alternative organic products with fungicide effect in apple cultivars. Notulae Botanicae Horti Agrobotanici ClujNapoca 46(1):115-121.

Musacchi S, Serra S (2018). Apple fruit quality: overview on pre-harvest factors. ScientiaHorticulturae 234:409-430.

NMX-FF-061-SCFI (2003). Productos agrícolas no industrializados para consumo humano - fruta fresca-manzana (Maluspumila Mill) - (Malus domestica Borkh) - Especificaciones [Non-ndustrialized agricultural products for human consumption - fresh fruit - apple (Malus pumila Mill) - (Malus domestica Borkh) - Specifications]. Cancela a la NMXFF-061-1993-SCF.

Pérez-Pérez E, Nava A, González C, Marín M, Sandoval L, Casassa-Padrón AM,... Fernández C (2008).Efecto de la aplicación de sulfato de calcioy materia orgánica sobre la incidencia de la pudrición apical de la guayaba (Psidium guajava L.). [Effect of the application of calcium sulfate and organic matter on the incidence of apical rot of guava (Psidium guajava L.)] Revistade la Facultad de Agronomía 25(3):507-524.

Ranjbar S, Rahemi M, Ramezanian A (2018). Comparison of nano-calcium and calcium chloride spray on postharvest quality and cell wall enzymes activity in apple cv. 'Red Delicious'. Scientia Horticulturae 240:57-64.

Ramezanian A, Rahemi M, Vazifehshenas MR (2009). Effects of foliar application of calcium chloride and urea on quantitative and qualitative characteristics of pomegranate fruits. Scientia Horticulturae 121(2):171175.

Rodríguez AM, Güemes D, Benavides MJ, Rivas MZ, Pirovani MÉ, Piagentini AM (2013). Evaluación preliminar del efecto del tratamiento químico sobre atributos fisicoquímicos, sensoriales y bioactivos de manzanas frescas cortadas [Preliminary evaluation of the effect of chemical treatment on physicochemical, sensory and bioactive attributes of fresh cut apples]. Revista Iberoamericana de Tecnología Postcosecha 14(2):223-229.

Romero DL, Parra QR, Jacobo CJ, Barrios OL, Guerrero PV, Ruiz AT (2017). Respuesta de portainjertos de manzano a vigor, eficiencia de producción y concentraciones foliar y en fruto de NPK [Response of apple rootstocks to vigor, yield efficiency and leaf and fruit concentrations of NPK]. Revista Mexicana de Ciencias Agrícolas 8(4):849-861.

Romero-Gomezcaña NR, Sánchez-GarcíaP, Rodríguez-AlcázarJ, SaucedoVeloz C (2006). Aplicación foliar de calcioy su relación con la calidad en frutos de mango cv. Haden [Calcium foliar sprinkling and its relation with fruit quality of mangoes cv. Haden].Agricultura Técnica en México 32(1):5-15.

SAGARPA (2017). Producción agrícola nacional. Retrieved 2018 December 27 from https://www.gob.mx/cms/uploads/attachment/ file/256430/B_sico-Manzanapdf.

Seipel M, Pirovani ME, Gúemes DR, Gariglio NF, Piagentini AM (2009). Características fisicoquímicas de los frutos de tres variedades de manzanas cultivadas en la región centro-este de la provincia de Santa Fe [Physicochemical characteristics of the fruits of three varieties of apples grown in the central-eastern region of the province of Santa Fe]. Revista FAVE-Ciencias Agrarias 8(1):28-36.

Silveira AC, Sautter CK, De Freitas ST, Galietta G, Brackmann A. (2007). Determinación de algunos atributos de calidad de la variedad Fuji y sus mutantes al momento de cosecha [Determination of some quality parameters of the Fuji cultivar and their mutants at harvest]. Ciencia e Tecnología de Alimentos Campinas 27(1):149-153.

Sió J, Bosch-Serr AD, Rosera J, Chiné J, Boixadera J (2018). Características de los suelos y su fertilidad en relación con la incidencia de bitter pit en plantaciones de manzanas Golden [Soil characteristics and fertility in relation to the incidence of bitter pit in Golden apple plantations]. Informacion Tecnica Economica Agrarian 114(3):206-222.

Soto Parra JM, Piña Ramírez FJ, Sánchez Chávez E, Pérez Leal R, Basurto Sotelo M (2016). Fertirrigación con macronutrientes en manzano 'Golden Delicious': Impacto en rendimiento y calidad de fruto [Fertirrigation with macronutrients in apple tree 'Golden Delicious' Impact on yield and fruit quality]. Nova Scientia 8(16):162-180.

Soto PJM, Piña RFJ, Sánchez ChE, Torres BNG, Flores PJB, Basurto SM, Pérez LR (2015). Uso de enmiendas cálcicas-orgánicas y microorganismos potenciadores de la fertilidad del suelo [Use of calcium-organic amendments and soil fertility enhancing microorganisms]. In: Nutrición Mineral de las Plantas Agricultura Sustentabley Protegida pp 129-154.

Torres E, Recasens I, Lordan J, Alegre S (2017). Combination of strategies to supply calcium and reduce bitter pit in 'Golden Delicious' apples. ScientiaHorticulturae 217:179-188.

Wang R, McCormick R, Xuan H, StreifJ (2008). Distribution of sugar and organic acid components within the KOB heritage apple cultivar collection. In: III International Conference Postharvest Unlimited pp 89-97.

Zermeño-González A, Gil-Marín JA, Ramírez-Rodríguez H, HernándezHerrera A, Rodríguez-García R, Benavides-Mendoza A, Jasso-Cantú D (2009). Efecto del encalado total del manzano en la temperatura interna, rendimiento de frutos y su relación con la aplicación de thidiazuron [Effect of total white washing of apple tree on its internal temperature, fruit yield and its relation to use of thidiazuron]. Revista Chapingo. Serie Horticultura 15(3):289-296. 